genomics bieden een solide basis voor het ontwerpen van een gestandaardiseerd meetinstrument voor de familieanamnese in de JGZ.
1 Vakgroep Sociale Geneeskunde, School for Public Health and Primary Care (CAPHRI) en 2 Vakgroep Health, Ethics and Society, School for Oncology and Developmental Biology (GROW), beide Faculty of Health,
Medicine and Life Sciences, Universiteit Maastricht; 3 Centre for Society and the Life Sciences (CSG), Nijmegen

Informatie:

e.syurina@maastrichtuniversity.nl

\section{De familieanamnese bij \\ psychosociale problemen in de jeugdgezondheidszorg. Wordt deze gebruikt? Casus Zuid-Nederland}

E.V. Syurina, ${ }^{1}$ K. Hens, ${ }^{2,3}$ W. Dondorp ${ }^{2}$ en F.J.M. Feron ${ }^{1}$

\section{Achtergrond en doelstelling} Aandoeningen die veel voorkomen, hebben vaak een sterke genetische achtergrond, zo blijkt uit wetenschappelijk onderzoek. Dat geldt ook voor psychosociale problemen. Door de American Academy of Pediatrics (AAP) wordt dan ook aanbevolen om familieanamnestische informatie te benutten in de dagelijkse praktijk van de eerstelijnsgezondheidszorg. Wij onderzochten in welke mate de familieanamnese gebruikt wordt in de praktijk van de jeugdgezondheidszorg (JGZ) wanneer een indicatie voor de geestelijke gezondheidszorg (jeugd-ggz) is gesteld.

Methode

Wij maakten gebruik van data uit de sociaal-medische JGZ-dossiers van kinderen voor wie een indicatie is gesteld voor hulpverlening in de jeugd-ggz. Aan de hand van de dossierregistraties is bij een JGZdienst in het Zuiden van Nederland informatie verzameld over de familieanamnese aan de hand van 15 criteria (o.a. beschikbaarheid, update, tijdstip van afname, inhoud, uitgebreidheid).

\section{Resultaten}

De dossiergegevens van 474 kinderen (31,5\% meisjes) zijn geanalyseerd met SPSS. Van $88,3 \%$ van deze kinderen is een bij de geboorte afgenomen familieanamnese beschikbaar. In de helft van de gevallen is deze informatie bijgewerkt als het kind 5-6 jaar was. Meestal blijft de familieanamnese beperkt tot eerste- en tweedegraads familieleden, en is alleen gevraagd naar formele diagnoses. De leeftijd waarop bij familieleden een diagnose was gesteld, ontbreekt in vrijwel alle dossiers. Een onbelaste familieanamnese is zelden als zodanig geregistreerd: uit ontbrekende gegevens is immers geen blanco familieanamnese af te leiden. Gegevens over de familieanamnese zijn overigens vaker terug te vinden in de specialistenbrieven dan in de verwijsbrieven.

Conclusie

Het belang van de familieanamnese staat niet ter discussie in de JGZ, maar uit ons onderzoek blijkt dat er sprake is van onderregistratie. Tevens blijkt dat de internationale aanbevelingen van de AAP meestal niet worden gevolgd, in het bijzonder waar het gaat om registreren en bijwerken van de familieanamnese.

1 Vakgroep Sociale Geneeskunde, School for Public Health and Primary Care (CAPHRI) en 2 Vakgroep Health, Ethics and Society, School for Oncology and Developmental Biology (GROW), beide Faculty of Health, Medicine and Life Sciences, Universiteit Maastricht; 3 Centre for Society and the Life Sciences (CSG), Nijmegen

Informatie:

e.syurina@maastrichtuniversity.nl
Kinderen met cerebrale parese op school: barrières en kansen

\section{Van Trimpont, ${ }^{1}$ F. De Boeck, ${ }^{2}$ \\ P. De Cock, ${ }^{1}$ K. Pétry ${ }^{3}$ en \\ K. Hoppenbrouwers ${ }^{1}$}

\section{Achtergrond en doelstelling} Een toenemende proportie kinderen met een chronische aandoening groeien op tot volwassenen, en willen schoollopen in het gewoon onderwijs. Kinderen met cerebrale parese (CP) kennen functionele en andere beperkingen die de onderwijsparticipatie in belangrijke mate kunnen belemmeren. Doelstellingen zijn het evalueren van de huidige praktijk in scholen van het gewoon onderwijs in Vlaanderen in het omgaan met kinderen met cerebrale parese $(\mathrm{CP})$.

\section{Methode}

Een ziektespecifieke vragenlijst is ontwikkeld op basis van literatuuronderzoek om de impact van kindkenmerken (leerproblemen, functiebeperkingen, schoolabsenteïsme), klasfactoren (attitude van medeleerlingen), ondersteuning van de Specifieke Onderwijsbehoeften (SO) en schoolfactoren (toegankelijkheid en veiligheid van gebouwen), op schoolparticipatie van kinderen met 